\title{
SOIL TEMPERATURE AND DIAPAUSE MAINTENANCE IN EGGS OF THE SPITTLEBUG, Deois flavopicta (HEMIPTERA: CERCOPIDAE)
}

\author{
SUJII, E. R., ${ }^{1}$ GARCIA, M. A., ${ }^{2}$ FONTES, E. M. G., ${ }^{1}$ SILVA, S. M. B. da ${ }^{1}$, and \\ MEYER, J. F. C. A. ${ }^{3}$ \\ ${ }^{1}$ Laboratório de Bioecologia e Semioquímicos de Insetos, Embrapa/Cenargen, C.P. 02.372, \\ CEP 70849-970, Brasília, DF, Brazil \\ ${ }^{2}$ Departamento de Zoologia, IB, Unicamp, C.P. 6.109, CEP 13083-970, Campinas, SP, Brazil \\ ${ }^{3}$ Departamento de Matemática Aplicada, IMECC, Unicamp, C.P. 6.065, CEP 13083-970, Campinas, SP, Brazil \\ Correspondence to: Edison Ryoiti Sujii, Embrapa/Cenargen, PqEB W5 Norte Final, C.P. 02.372, \\ CEP 70849-970, Brasília, DF, Brazil, e-mail: sujii@ cenargen.embrapa.br \\ Received August 22, 2000 - Accepted November 17, 2000 - Distributed November 30, 2001
}

(With 4 figures)

\begin{abstract}
Diapausing eggs of the neotropical pasture pest, Deois flavopicta (Stal) (Hemiptera: Cercopidae), were exposed to low overnight temperatures that simulated field conditions during the dry season (23/12, $23 / 15$ and $23 / 18^{\circ} \mathrm{C}$ day/night), for different periods (0-60 days). After treatment, eggs were kept at $28^{\circ} \mathrm{C}$ and contact water (100\% humidity) until hatching. A group of diapausing eggs were kept all the time under this last condition as a control treatment. Time for hatching (in degree-days) was reduced with decrease in low overnight temperature and increase of exposure time to these cold shocks, although there was no interaction between the factors. Regression of exposure time to cold shock influencing the expected mean hatching time produced independent equations for temperatures below $18^{\circ} \mathrm{C}$ and $15^{\circ} \mathrm{C}$. We constructed a model that simulates the expected proportion of the population hatching after the beginning of rainy season based on regression equations to mean hatching time and associated standard deviation. The simulation generated for the model correlated significantly with nymphal population observed in the field. These results showed that overnight soil temperatures below $18^{\circ} \mathrm{C}$, as occurs in Central and South-eastern Brazil between May and August, shorten the period of diapause, increase quiescent eggs in the soil, and may synchronize the population hatching.
\end{abstract}

Key words: Insecta, phenology, dormancy, cold treatment, population dynamics.

\section{RESUMO}

Temperatura do solo e manutenção da diapausa em ovos da cigarrinha-das-pastagens, Deois flavopicta (Hemiptera: Cercopidae)

Foram expostos ovos diapáusicos da praga de pastagens na região neotropical, Deois flavopicta (Stal) (Hemiptera: Cercopidae), a baixas temperaturas noturnas, simulando condições de campo durante a estação seca $\left(23 / 12,23 / 15\right.$ e $23 / 18^{\circ} \mathrm{C}$ dia/noite), por diferentes períodos $(0,15,30,40,50$ e 60 dias). Após o tratamento térmico, os ovos foram mantidos a $28^{\circ} \mathrm{C}$ e em água de contato ( $100 \%$ de umidade), até a eclosão das ninfas. Um grupo-controle de ovos diapáusicos foi mantido por todo o período experimental em altas temperaturas e umidade. O tempo para eclosão (em graus/dia) foi reduzido devido ao efeito das baixas temperaturas noturnas e ao aumento no período de exposição ao choque frio, embora não tenha sido observada interação significativa entre esses fatores. A regressão do efeito do período de choque frio no tempo médio para eclosão das ninfas provenientes de ovos diapáusicos produziu equações independentes para as temperaturas abaixo de $18^{\circ} \mathrm{C}$ e $15^{\circ} \mathrm{C}$. Com base nas equações 
de regressão do tempo médio e no desvio-padrão associado, construímos um modelo que simula a proporção esperada da população que eclodirá após o início da estação chuvosa. A simulação gerada pelo modelo correlacionou-se significativamente à população de ninfas observada no campo. Estes resultados mostram que temperaturas noturnas abaixo de $18^{\circ} \mathrm{C}$, como ocorre no Centro-Sul do Brasil entre maio e agosto, abreviam o período da diapausa, acumulam ovos quiescentes no solo e podem sincronizar a eclosão da população.

Palavras-chave: Insecta, fenologia, dormência, choque frio, dinâmica populacional.

\section{INTRODUCTION}

In central Brazil the rainy warm season, when grasses develop and reproduce, alternates with the dry cool season, when dormancy prevails. In this landscape, a species-complex of spittlebugs, known as pasture spittlebugs (Homoptera: Cercopidae), is the main pest problem in cultivated pastures (Valério \& Koller, 1992; Valério \& Nakano, 1987). In the savanna-like areas, known as Cerrado, the main species is Deois flavopicta (Stal), 1854 (Botelho \& Reis, 1980; Cosenza \& Naves, 1980). This species avoids adverse conditions by diapausing in the egg stage. Females vary in the proportions of diapausing and non-diapausing eggs that they lay during the rainy season; moreover the duration of diapause is variable within populations (Fontes et al., 1995; Koller, 1991).

Without any apparent diapause terminating cues, hatching extends from July through December, with a peak in September/October (Sujii et al., 1995, Fontes et al., 1995; Koller, 1991). In central Brazil this peak coincides with the transition between dry and rainy seasons.

Dormancy in eggs of $D$. flavopicta has, at least two distinct parts: diapause and post-diapause quiescence (Pires et al., 2000). Neither photoperiod (Pires et al., 1991) or temperature and humidity (Pires et al., 2000), are apparently used as environment cues for diapause termination in $D$. flavopicta.

On the contrary, Sujii et al. (1995) observed that diapausing eggs experiencing an overnight low temperature of $15^{\circ} \mathrm{C}$ for $>8 \mathrm{~d}$, during the dry season, terminate dormancy and hatch earlier and within a synchronized period.

The present study examined the effect of low overnight temperatures (duration and intensity of exposure) on the maintenance and termination of diapause in D. flavopicta. Initially, the study takes an experimental approach; subsequently, the data are modeled and tested against emergence pattern of first instar in the field. It is our expectation that precise understanding of the phenology of this insect will allow forecasting of first instar populations in the field, and significantly improve the pest management program of this insect.

\section{MATERIAL AND METHODS}

\section{Study sites}

This work was conducted in the Distrito Federal, Brasília, which is located in the western region of central Brazil (15 $\left.40^{\circ} \mathrm{S}, 47^{\circ} 40^{\prime} \mathrm{W}\right)$. Field experiments were conducted in pastures of $\mathrm{Bra}$ chiaria ruziziensis Stapf and $B$. decumbens Stapf (Poaceae), in experimental fields of the Brazilian Agricultural Research Organization - Center for Agriculture Research in the Cerrados (Embrapa Cerrados), and the Agriculture High School of Brasília (CAB). Laboratory experiments were carried out at EMBRAPA's Center for Agriculture Research in Genetic Resources and Biotechnology (Embrapa/Genetic Resources and Biotechnology) at the Biological Control facilities.

The weather in that region is characterized as warm and rainy with dry winters (Garrido et al., 1982). Mean annual rainfall is $1,537 \mathrm{~mm}$ with $96 \%$ of precipitation occurring from September through April.

Rainfall rarely exceeds $30 \mathrm{~mm} / \mathrm{month}$ during the dry season (May-August). Average monthly temperature shows little variation $\left(19.8\right.$ to $\left.23.2^{\circ} \mathrm{C}\right)$ in relation to the diurnal variation which is frequently $>10^{\circ} \mathrm{C}$.

\section{Low temperatures and diapause termination}

From February to April, the period during which $D$. flavopicta lays a high percentage of diapausing eggs, adults were collected every week from pastures of Brachiaria ruziziensis using sweep-nets. In the laboratory, groups of 25 pairs 
were kept in oviposition cages. Each cage consisted of a clear plastic cylinder measuring $21 \mathrm{~cm}$ length, and $10 \mathrm{~cm}$ in diameter. Three of these cylinders were placed in an aluminum tray containing a 1 $\mathrm{cm}$ layer of agar ( $20 \mathrm{~g}$ of agar and $0.45 \mathrm{~g} \mathrm{ZnSO}$ per liter of water). The agar surface was rutted with a knife to form $0.5 \mathrm{~cm}$ squares to provide better support and facilitate ovipositor insertion. Seedlings of Brachiaria decumbens served as food for the insects in each cage. Plants were kept fresh by immersing their roots in water in a small vial or an Erlenmeyer flask covered with aluminum foil (modified from Valério, 1993; Koller, 1991; Magalhães et al., 1987). The top of the cage was covered with nylon net. Eggs were collected from the agar 2 or 3 days after placing the adults in the cage. The eggs were then washed in a $0.5 \%$ sodium hypochlorite solution. Groups with 25 randomly selected eggs were placed in Petri dishes lined with a thin layer of moistened cotton and filter paper.

Groups of 4 Petri dishes, forming a total of 100 eggs per treatment, were exposed to temperature regimes of $23 / 12,23 / 15$, and $23 / 18^{\circ} \mathrm{C}$ (day/ night) for periods of $0,15,30,40,50$, and 60 days, in environmental chambers. Day temperature of $23^{\circ} \mathrm{C}$ was used because this is the average daytime temperature during the period of May through August when the main proportion of diapausing eggs stays dormant in the field. The photoperiod used during the experiment was 12.5 hours of photophase. All eggs were constantly exposed to moist conditions. A control treatment consisted of 4 Petri dishes with 25 eggs each which were kept constantly under $28^{\circ} \mathrm{C}$ temperature and moisture was monitored in order to evaluate hatching distribution of diapausing eggs in the absence of low overnight temperature.

After having completed the cold treatments, eggs were transferred to another incubator and kept at a constant temperature of $28 \pm 2^{\circ} \mathrm{C}$, and in moist conditions until hatching. Eggs were monitored every other day, and hatched nymphs and their respective chorions were counted and removed from the dishes. Eggs that changed color (became white or grayish) or shape (became flattened) were considered to have died and were removed.

The time from the beginning of cold treatment, June $1^{\text {st }}$, until hatching was converted into degree-days above a lower thermal threshold of $13.7^{\circ} \mathrm{C}$ for development, as determined by Sujii et al. (1995). This procedure allowed for correction of temporal effect of treatments, thus comparisons among the results were possible. The effect of low overnight temperature and exposure time on the average time for egg hatching was evaluated by a factorial analysis of variance. This test was followed by Student Newman Keuls Test to compare mean values (Kuo et al., 1992). Nondiapausing eggs were eliminated from the experiment because they do not survive the adverse conditions of the dry season (Fontes et al., 1995).

\section{Data modelling}

Average time for egg hatching in the laboratory was modeled through linear regression to simulate occurrence of first generation nymphs in the field. The standard deviation associated with average hatching time was regressed against the duration low temperature exposure. Because the egg hatching pattern fit normal distribution, we could use the average hatching time and its standard deviation to calculate the standardized $\mathrm{Z}$ variable (Snedcor \& Cochran, 1980).

It was then possible to estimate a theoretical curve for the accumulated frequency of egg hatching in degree-days above $13.7^{\circ} \mathrm{C}$ (the lower developmental threshold), based on periods of egg exposure to low temperatures.

Weather conditions were monitored in the field during the dry season. These data were used with the simulation model to produce a curve of expected accumulated egg hatching in the next year's first generation.

This curve was compared with the empirical curve of egg hatching observed in a field population that year. The weather information was obtained from the weather station of Embrapa Cerrados, c.a. $6 \mathrm{~km}$ distant from the pastures where the population was surveyed. The population of first instars was monitored weekly. Each sample, consisting of $25 \mathrm{~cm}^{2}$, was randomly thrown a hundred times in the area. The observed and expected curves for egg hatching time were compared with those of the Kolmogorov-Smirnov test for two samples (Wilkinson, 1990).

All statistical analyses were performed with software from Systat Inc. (Wilkinson, 1990) and Jandel Scientific (Kuo et al., 1992). 


\section{RESULTS}

The factorial variance analysis showed that the main effect of all factors, and low overnight temperature and exposure period, are significant and reduced the time hatching, although there was no interaction between the factors (Table 1). Comparisons of night temperature effects revealed that the average hatching time decreased progressively from control treatment, 18 and $15^{\circ} \mathrm{C}$, and became stable from 15 to $12^{\circ} \mathrm{C}$ (Fig. 1). Plotting the average times for egg hatching related with period of exposure to low overnight temperature of $18^{\circ} \mathrm{C}$ allowed adjustment of the equation (Fig. 2a)

$$
\mathrm{HT}=1,128-8.61 \times \mathrm{D}_{18}+0.0008 \times\left(\mathrm{D}_{18}\right)^{3}
$$

where:

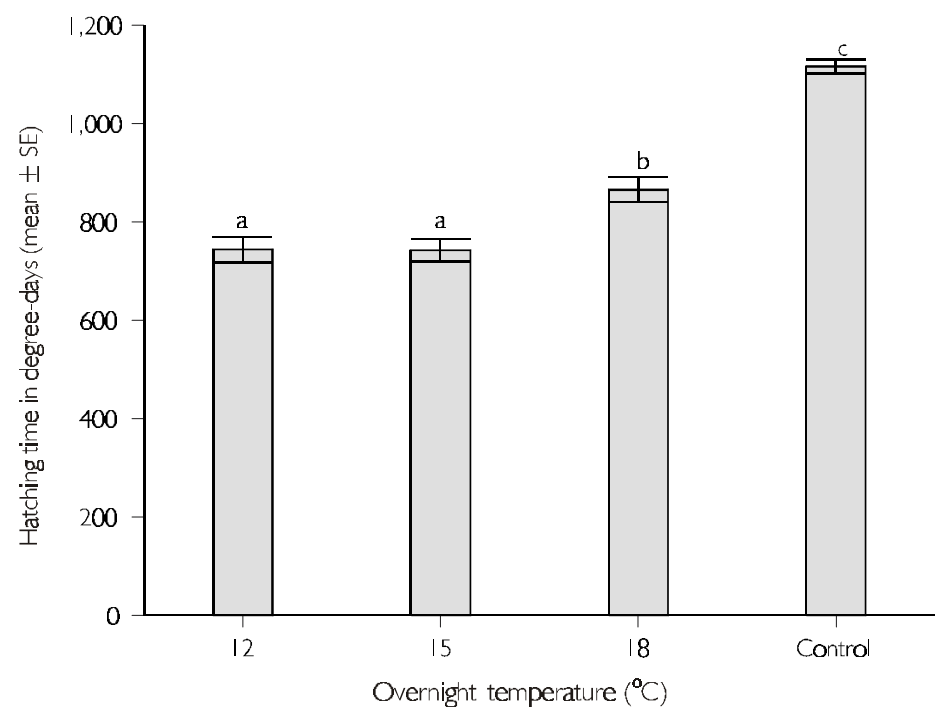

$\mathrm{HT}=$ time required for hatching (degree-days);

$\mathrm{D}_{18}=$ number of days during which soil temperature at night $\leq 18^{\circ} \mathrm{C}$.

The same procedure was done to adjust a curve to fit the average hatching time for diapausing eggs exposed to overnight temperature of 15 and $12^{\circ} \mathrm{C}$ (Fig. 2b), resulting the follow equation: where:

$$
\mathrm{HT}=1,115.79-12.51 \times \mathrm{D}_{15}+0.0013 \times\left(\mathrm{D}_{15}\right)^{3}
$$

$\mathrm{HT}=$ time required for hatching (degree-days);

$\mathrm{D}_{15}=$ number of days during which soil temperature at night was $\leq 15^{\circ} \mathrm{C}$.

The two equations above were combined in a function to simulate the expected average hatching time for diapausic eggs of $D$. flavopicta exposed to any period of low overnight temperature.

Factorial analysis of variance of mean hatching time of the spittlebug Deois flavopicta's diapausic eggs (average of four replicates).

\begin{tabular}{|l|c|c|c|c|c|}
\hline \multicolumn{1}{|c|}{ Source } & df & SS & MS & F & P \\
\hline Treatments & 15 & $1,234,422$ & 82,294 & 51.18 & $<0.001$ \\
\hline Control $v s$. others & 1 & 414,710 & 414,710 & 26.67 & $<0.001$ \\
\hline \hline Night temperature (NT) & 2 & 200,529 & 100,264 & 61.17 & $<0.001$ \\
\hline Exposure period (EP) & 4 & 597,863 & 149,465 & 89.70 & $<0.001$ \\
\hline NT $\times$ EP & 8 & 21,318 & 2,664 & 1.60 & 0.152 \\
\hline Error & 60 & & & & \\
\hline
\end{tabular}

Note $: \mathrm{df}=$ degrees of freedon; $\mathrm{SS}=$ sum os squares; MS mean square; $\mathrm{F}=$ fratio; $\mathrm{P}=$ probability. 

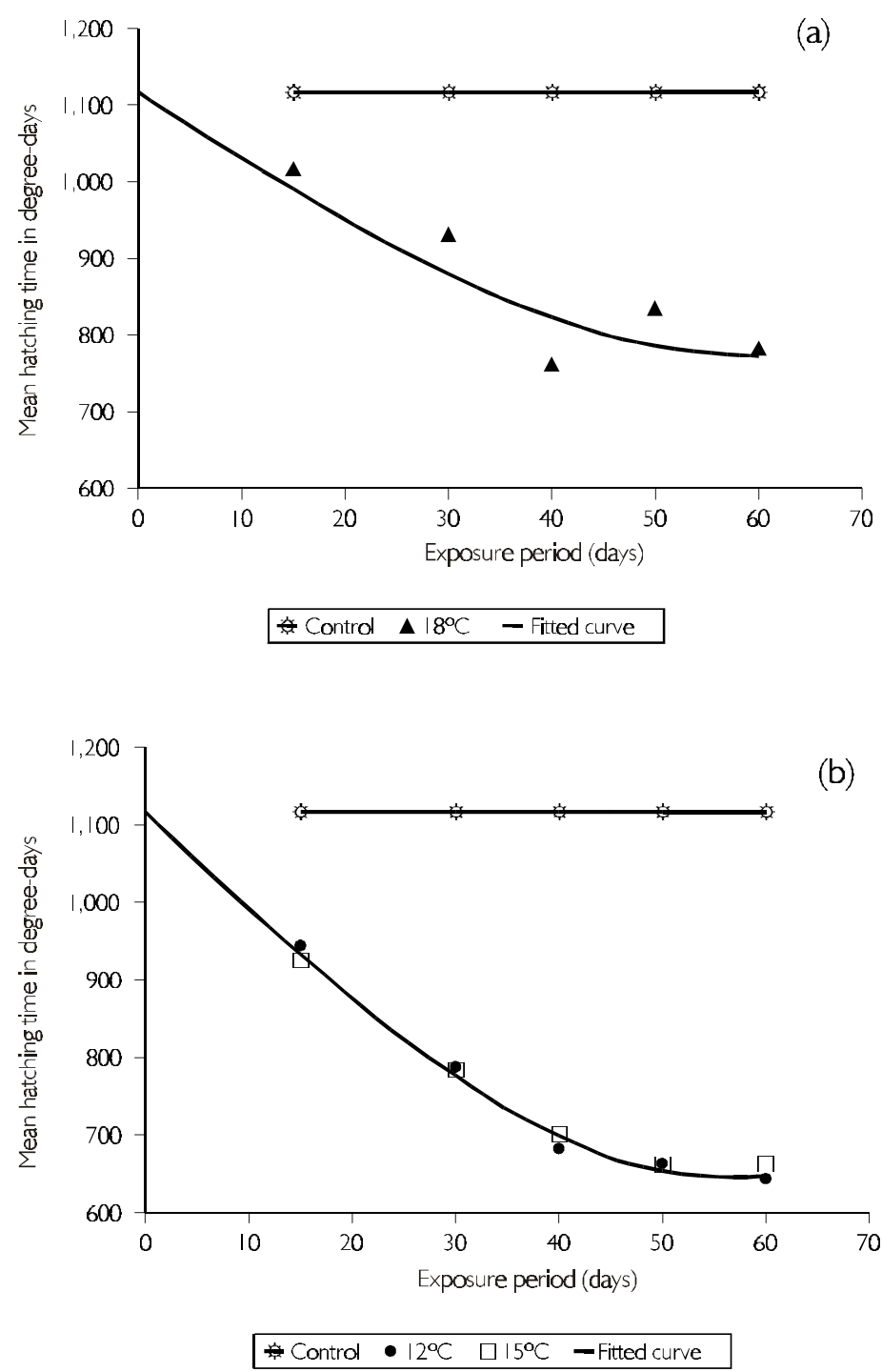

Fig. 2 - Regression anlysis adjusting a curve to model the effect of period of exposure to low overnight temperature on the mean hatching time of Deois flavopicta's diapausing eggs. a) cold shock of $18^{\circ} \mathrm{C}$; b) cold shock of $15^{\circ} \mathrm{C}$ or below.

Resulting model has a constant obtained from the average hatching time of the control treatment and the slope determining terms mean weighted from both equations:

$$
\begin{aligned}
\mathrm{HT}= & 1,116.75-\left(8.61 \times \mathrm{D}_{18}\right)-\left(12.51 \times \mathrm{D}_{15}\right)+ \\
& {\left[\left(0.0008 \times\left(2 \times \mathrm{D}^{18}\right)^{3}\right)+(0.0013 \times(2 \times\right.} \\
& \left.\left.\left.\mathrm{D}_{15}\right)^{3}\right)\right] \times 2^{-1}
\end{aligned}
$$

where:

$\mathrm{HT}=$ time required for hatching (degree-days);
$\mathrm{D}_{18}=$ days during which soil temperature at night was $\leq 18^{\circ} \mathrm{C}$ and $>15^{\circ} \mathrm{C}$;

$\mathrm{D}_{15}=$ days during which soil temperature at night was $\leq 15^{\circ} \mathrm{C}$.

A synchrony of hatching time was observed when the diapausic eggs were exposed to the cold treatments for increasing periods. This phenomenon is showed through the decrease of standard deviation of the average hatching time, in Fig. 3. Standard deviations associated with the average time for egg 
hatching were inversely related to the time of exposure to cold temperatures, in a spatial pattern similar to that of the time taken for egg hatching (Fig. 3). This indicates that low overnight temperature $<18^{\circ} \mathrm{C}$ and period of exposure determines not only average time for eggs hatching but also the standard deviation of this mean, and it regulates egg hatching synchrony. The standard deviations were modeled using linear regression, similarly to the average time for egg hatching.

The resulting equation of this analysis was:

$$
\mathrm{SD}=195.87-1.99 \times \mathrm{D}\left(\mathrm{r}^{2}=0.885, \mathrm{n}=16, \mathrm{~F}=\right.
$$$$
49.99, \mathrm{p}<0.001)
$$

where

$\mathrm{SD}=$ standard deviation of the mean in degree-days necessary for egg hatching for the equivalent cold treatment;

$\mathrm{D}=$ number of days with soil minimum temperature $<18^{\circ} \mathrm{C}$.

This model allows simulating the standard deviation of the mean hatching time of postdiapausing eggs for each low overnight temperature exposure.
To predict the occurrence of first instars nymphs of the first generation in the field, we used the number of days and the mean of minimum soil temperatures $<18^{\circ} \mathrm{C}$ during the dry season (May through August). Using the monthly average temperature between June 1 and the beginning of the rainy season, with rainfall $>30$ $\mathrm{mm}$, it was possible to predict hatching egg distribution through the standardization of the mean and standard deviation with the $\mathrm{Z}$ variable of the normal distribution to simulate the accumulated proportion of hatching eggs.

Monitoring the occurrence of first instar nymphs in the beginning of the rainy season, in two separate pasture fields in the Federal District, showed that our simulation using field weather conditions during the dry season and during the transition from dry to rainy season predicted the timing of egg hatching very well. The comparison of observed and simulated curves of accumulated proportion of hatching eggs showed a high degree of agreement when compared with the Kolmogorov-Smirnov test (Fig. 4).

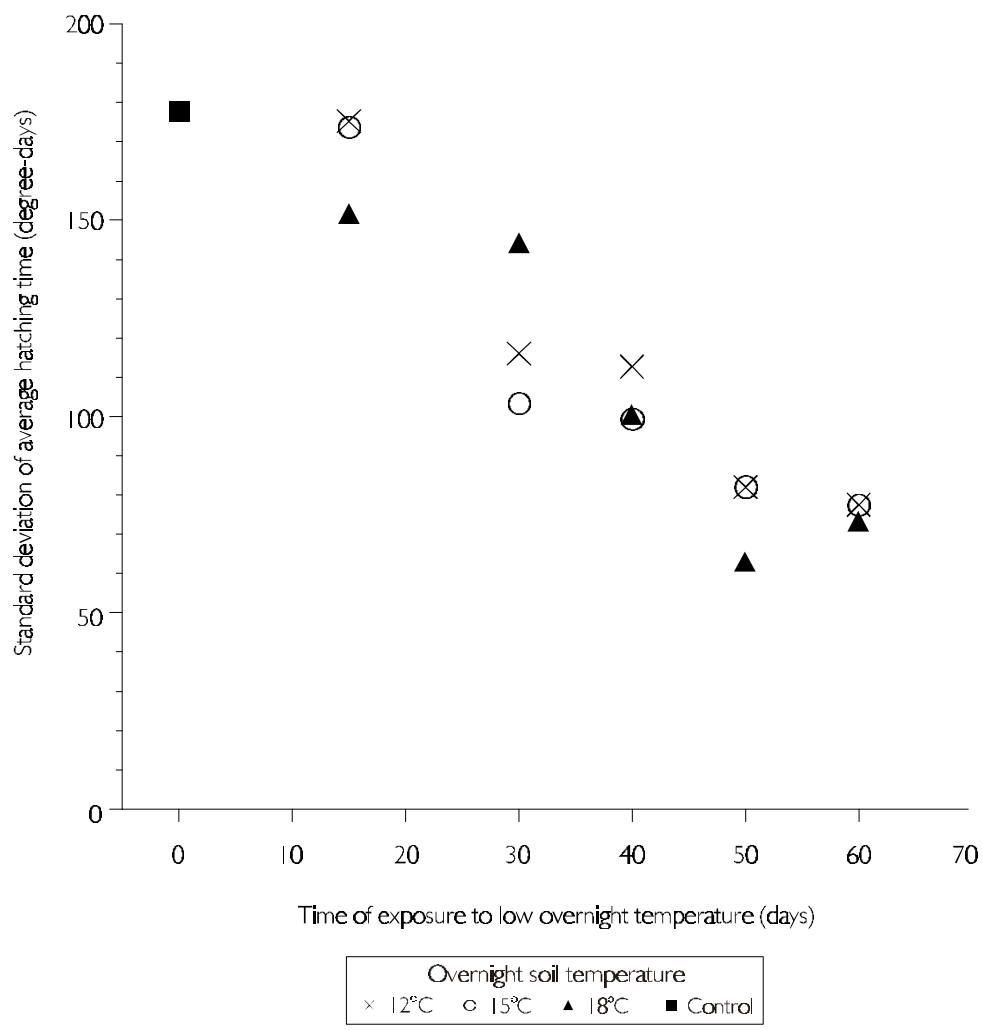

Fig. 3 - Distribution of the standard deviation related to the average hatching time of Deois flavopicta eggs exposed to different cold treatments. 


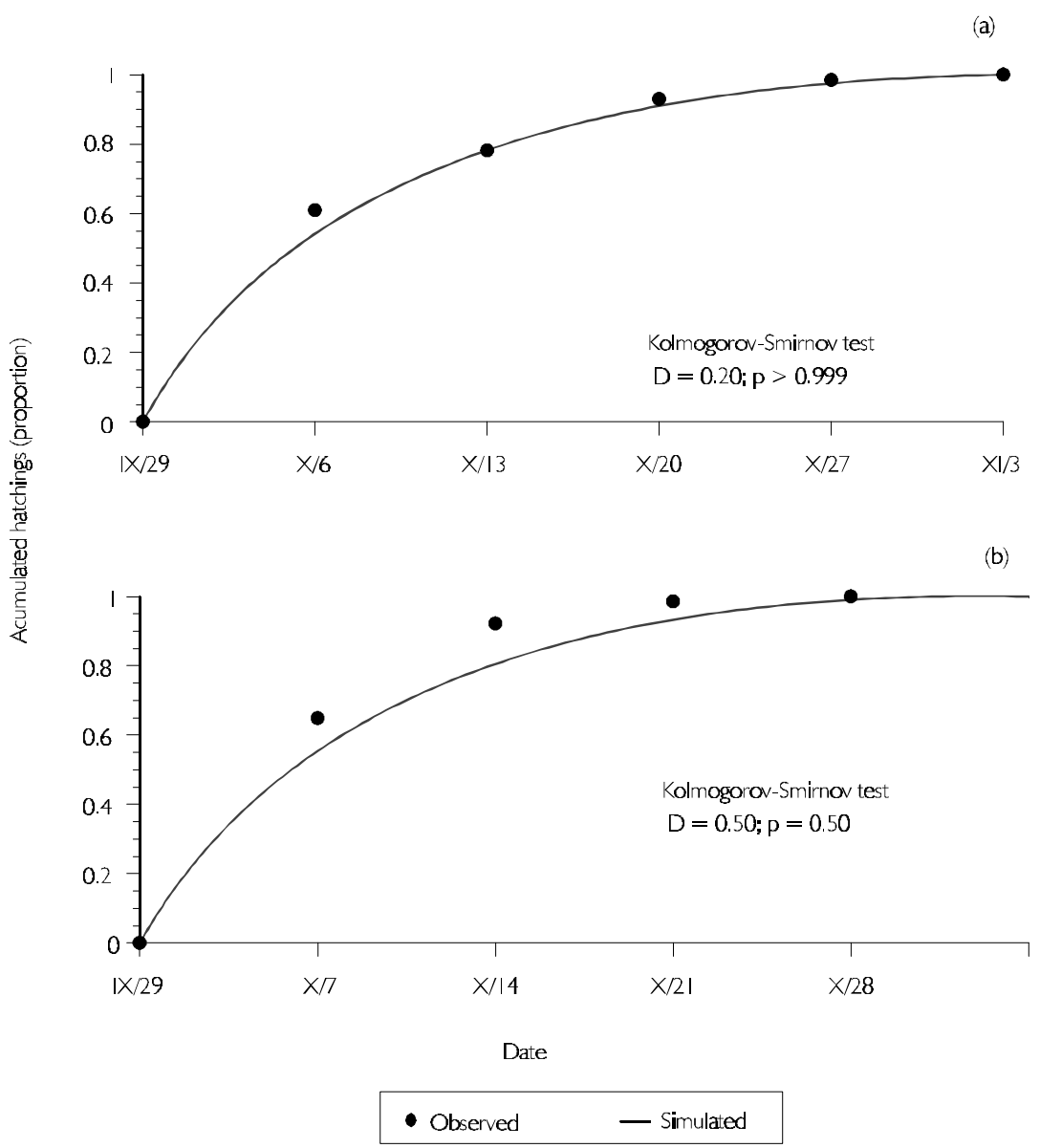

Fig. 4 - Comparison in two areas of the acumulated proportion distribution curves of hatched eggs observed under field conditions and simulated through the model developed for diapause eggs of Deois flavopicta. a) Embrapa Cerrados; and b) $\mathrm{CAB}$.

\section{DISCUSSION}

The present study supports the idea that the interaction between overnight soil temperatures and exposure time produced a thermal cold shock that reduced the expected time for egg hatching and increased hatching synchronization in the spittlebug population.

It is possible that the low temperature accelerated diapause development, but retarded postdiapause development, thus reducing the duration of the egg stage and synchronizing hatching after the eggs experienced warm condition (Pires et al., 2000; Tauber et al., 1986). When this happens, quiescence may be the mechanism through which the eggs maintain their low metabolic rate and drought hardiness after diapause has ended.
Under quiescence $D$. flavopicta eggs can resume embryonic development in response to favorable environmental conditions, thus synchronizing the annual life cycle with plant regrowth and food availability and quality (Fontes et al., 1995).

Observations on the control treatment, when eggs hatched between August and December with a peak in October, revealed that diapausic eggs of D. flavopicta exposed to favorable conditions since oviposition terminate diapause spontaneously, without any apparent environmental stimuli. Hatching time distribution occurred within a large range of variability among each population.

Diapausing eggs treated at low temperature hatched steadily faster and synchronized, supporting the above statements. 
Eggs of $D$. flavopicta exposed to any low temperature for a period $>40 \mathrm{~d}$ discontinued reduction of hatching time and synchronization as expected and tested in this and another study (Sujii et al., 1995). This may indicate that diapause had terminated in all or most eggs by the $40^{\text {th }} \mathrm{d}$ of exposure to low temperature.

The beginning of the rainy season means the return of the supply of water in the soil necessary for embryonic development and egg hatching. Water acts as a second factor influencing the end of dormancy of quiescent eggs present in the soil, waiting for favorable conditions to resume development (Fontes et al., 1995; Sujii et al., 1995). Observations that first population peak of spittlebugs only occurs after precipitation that had replaced the humidity soil deficit, in the beginning of rainy season (Reis et al., 1980), supports the idea that soil moisture availability in the transition period of dry to rainy season changes egg hatching pattern and nymph density. Therefore, rains early in the season find a smaller proportion of eggs ready to respond to moisture, the postdiapause stimulus for hatching. Thus first generation eggs are not well synchronized and the population is small and widely distributed temporally. On the other hand, a prolonged dry season probably favor synchronism of hatching in a large proportion of the population, resulting in outbreaks.

The high similarity between simulated and empirical curves from field observations of postdiapause eggs hatching during this study, and observations with other spittlebugs, such as Aeneolamia occidentalis Walk and Prosapia simulans Walk (Cercopidae) in Mexico showing larger and more synchronized populations in the first generations when rains are abundant and sudden starts in the beginning of the season (Oomen, 1975), support the above proposed hypotheses of interaction of temperature and rain distribution to explain the variation of $D$. flavopicta densities and confirm the importance of moisture as a seasonal cue in the life cycle of insect in tropical and subtropical regions, as proposed by Tauber et al. (1998).

The interaction of temperature and soil moisture may be an important seasonal cue instead of a photoperiod in several insects in any region of the world, as had been previously showed with the Colorado Potato Beetle by Tauber et al. (1994), and is presented here with D. flavopicta.
The construction of a simulator based on the model presented would help predict not only the timing of first generation nymphs in the field, but also the densities of the first generation of annual populations and could be useful in new pest management strategies.

Acknowledgments — We thank Sávio Paes and Carmen Pires for the help with the surveys and experiments, to Miguel Petrere for his advice and suggestions ${ }^{\circledR}$ on the statistical analysis Drs. Maurice and Catherine Tauber, Robert O'Neil, Marcos Farias and Alice Nagata for the reviewing the manuscript, and to Embrapa and CNPq (200603/97-3) for financial support in a $\mathrm{Ph} . \mathrm{D}$. program at Unicamp/Ecology.

\section{REFERENCES}

BOTELHO, W. \& REIS, P. R., 1980, Cigarrinhas-das-pastagens Homoptera - Cercopidae em Brachiaria decumbens sob diferentes cargas animais. In: Epamig. Projeto bovinos, cigarrinha-das-pastagens. Relatório 1974/79. Epamig, Belo Horizonte, pp. 101-111.

COSENZA, G. W. \& NAVES, M. A., 1980, O controle da cigarrinha-das-pastagens. Embrapa/CPAC, Brasília, 4p. (Embrapa/CPAC, Comunicado Técnico, 6).

FONTES, E. M. G., PIRES, C. S. S. \& SUJII, E. R., 1995, Mixed risk-spreading strategies and the population dynamics of a brazilian pasture pest, Deois flavopicta. Jour. Econ. Entomol., 88(5): 1256-1262.

GARRIDO, W. E., AZEVEDO, L. G. de \& JARRETA-JUNIOR, M., 1982, O clima da região dos cerrados em relação à agricultura. Embrapa/CPAC, Planaltina, DF, 37p. (Embrapa/CPAC, Circular Técnica 9).

KOLLER, W. W., 1991, Cigarrinhas-das-pastagens (Homoptera: Cercopidae): porcentagem de ovos diapáusicos ovipositados em diferentes datas do período de infestação e a sua relação com condições climáticas que precederam cada oviposição. Tese de Doutorado, UFPR, 106p.

KUO, J., FOX, E. \& MACDONALD, S., 1992, Sigmastat: statistical software for working scientists. Jandel Scientific, San Francisco.

MAGAlHÃES, B. P., PARRA, J. R. P. \& SILVA, A. de B., 1987, Técnica de criação e biologia de Deois incompleta em Brachiaria. Pesq. Agrop. Bras., 22(2): 137-144.

OOMEN, P. A., 1975, A population study of the spittlebugs, Aeneolamia occidentalis (Walk) and Prosapia simulans (Walk) (Homoptera: Cercopidae) in Mexican Pangola pastures. Z. Ang. Entomol., 79: 225-238.

PIRES, C. S. S., FONTES, E. M. G., LIMA, L. H. C. \& GOMES, D. F., 1991, Influência do fotoperíodo sobre o término da diapausa de Deois flavopicta (Homoptera: Cercopidae). p. 203. In: Cong. Bras. de Entomologia, 13. Resumos, SEB, Recife, Vol. 1, 366p.

PIRES, C. S. S., SUJII, E. R., FONTES, E. M. G., TAUBER C. A. \& TAUBER, M. J., 2000, Dry-season embryonic dormancy in Deois flavopicta (Homoptera: Cercopidae) roles of temperature and moisture in nature. Env. Entomol., 29(4): 714-720. 
REIS, P. R., SILVEIRA NETO, S., BOTELHO, W. \& GAIERAS, L. A. C., 1980, Flutuação populacional da cigarrinha-das-pastagens (Homoptera: Cercopidae) e condições climáticas que influenciam sua ocorrência. pp. 6065. In: Epamig. Projeto bovinos, cigarrinha-das-pastagens. Relatório 1974-1979. Epamig, Belo Horizonte, $153 \mathrm{p}$.

SNEDCOR, G. W. \& COCHRAN, W. G., 1980, Statistical methods. 7.ed. Iowa State University, Iowa, 507p.

SUJII, E. R., GARCIA, M. A., FONTES, E. M. G. \& CARVALHO, V., 1995, Efeito da temperatura e umidade sobre o término da diapausa de ovos e densidade populacional da cigarrinha-das-pastagens, Deois flavopicta (Stal) (Homoptera: Cercopidae). An. Soc. Entomol. Brasil., 24(3): 465-478.

TAUBER, M. J., TAUBER, C. A., NYROP, J. P. \& VILLANI, M. G., 1998, Moisture, a vital but neglected factor in the seasonal ecology of insects: hypothesis and tests of mechanisms. Env. Entomol., 27: 523-530.

TAUBER, M. J., TAUBER, C. A. \& NYROP, J. P., 1994, Soil moisture and postdormancy emergence of Colorado Potato Beetles (Coleoptera: Chrysomelidae): descriptive model and field emergence patterns. Env. Entomol. (23): 1485-1496.
TAUBER, M. J., TAUBER, C. A. \& MASAKI, S., 1986, Seasonal adaptations of insects. Oxford University Press, New York, 411p.

VALÉRIO, J. R., 1993, Obtenção de ovos de cigarrinhas (Homoptera: Cercopidae) em Ágar-água. An. Soc. Entomol. Brasil., 22(3): 583-590.

VALÉRIO, J. R. \& KOLLER, W. W., 1992, Proposição para o manejo integrado das cigarrinhas-das-pastagens. Embrapa/CNPGC, Campo Grande, 37p.

VALÉRIO, J. R. \& NAKANO, O., 1987, Danos causados pelo adulto de cigarrinha-das-pastagens Zulia entreriana (Berg, 1879) (Homoptera: Cercopidae) em plantas de Brachiaria decumbens Stapf mantidas em diferentes níveis de umidade. An. Soc. Entomol. Brasil., 16(2): 341350 .

WILKINSON, L., 1990, Systat: The System for statistics: Statistics. Evanson, Illinois, Systat Inc., 676p. 